\title{
Prestidigitation vs. Public Trust: Or How We Can Learn to Change the Conversation and Prevent Powers From "Organizing the Discontent"1
}

\author{
Leigh E. Rich
}

Received: 1 December 2016 / Accepted: 10 January 2017 /Published online: 15 February 2017

(C) Journal of Bioethical Inquiry Pty Ltd. 2017

When Drs. Silvia Camporesi, Mark Davis, and Maria Vaccarella (2017) approached the Journal of Bioethical Inquiry about a symposium on "Public Trust in Expert Knowledge" as well as a panel session at the October 2016 meeting of the American Society for Bioethics + Humanities in Washington, D.C. (Camporesi et al. 2016), two books immediately sprang to mind.

The first was Strangers at the Bedside by David Rothman (2009, originally published in 1991). Subtitled A History of How Law and Bioethics Transformed Medical Decision Making, Rothman describes his book as an attempt to understand "how bedside ethics gave way to bioethics" $(2009,11)$. His central thesis revolves around the concept of trust - and the erosion of trust within medicine. From a U.S. vantage point (although the Unites States is not alone in this metamorphosis), Rothman critically examines how the rise of human experimentation, especially in "The Gilded Age of Research" following World War II, the distancing of doctor from patient in

\footnotetext{
${ }^{1}$ In the film Merchants of Doubt (Kenner et al. 2014), former South Carolina Congressman - and former climate-change denier-Bob Inglis commented on how difficult it is to challenge the views of, or even engage in honest conversation with, partisan think tanks like Americans for Prosperity (or any politician, media personality, individual, and business or organization who uses PR sleight-ofhand to generate doubt among the public and argue their own predetermined, self-interested ends with regard to issues affecting the public interest): "They're able to organize that discontent."
}

L. E. Rich $(\bowtie)$

Department of Health Sciences (Health Services Administration), Armstrong State University, 11935 Abercorn Street, University

Hall 154F, Savannah, GA 31419, USA

e-mail: leigh.rich@armstrong.edu terms of social demographics, culture, and connection to a common community, and rapid advances in biotechnology have helped increase expert knowledge. However, this has often come at the expense of unacceptable costs, such as wartime medical researchers carrying out studies from a bastardarized utilitarian perspective that prioritized "urgency" and the need for all citizens, including child, mental health patient, prisoner, or conscientious objector - and whether knowingly or not - to play their part. "Hands-off" policies within universities, the National Institutes of Health, and the U.S. Senate allowed postwar researchers continued freedom from oversight, and, as Rothman emphasizes, policymakers and participants alike conflated researchers' aims with a doctor's duty of care and therefore trusted them to act in the best interests of their subjects (and disregard the inherent conflicts that exist in this relationship). And although the concept of consent was neither non-existent nor new (having at least been acknowledged in the clinical encounter and the law), because the Allies were "not Nazis," there was little self-reflection, recognition of moral abuses, or changes in medicine or medical research until whistle-blowers like Maurice Pappworth and Henry Beecher (Harkness, Lederer, and Wikler 2001; Beecher 1966) or Jean Heller (1972) of the Associated Press, with help from Peter Buxtun, published their exposés about clinical experimentation or governmental research like Tuskegee. ${ }^{2}$

\footnotetext{
${ }^{2}$ In the United States, efforts also were being made by senators in the late 1960s for a commission to explore ethical issues in medicine, prompted by rapid advances in organ transplantation but also looking ahead to anticipated changes and growth in biotechnologies (Rothman 2009).
} 
As Rothman describes, this history, alongside changes in society, medical education, and science and industry, also transformed the physician into stranger-and, by doing so, invited additional experts into the clinical encounter and underscored the need for a more formal and more inter-professional bioethics.

Thus, in large part, bioethics is born of questions of trust in expert knowledge.

But it also gives birth to the means for establishing or re-establishing trust within healthcare and health policy.

When reading Rothman's book, many might first think Rothman rather sceptical of the move from caseby-case bedside ethics to a more formal bioethics. However, Rothman, in his analysis, is perhaps just honest about both the merits and the prices of this change. While bioethics has offered an increase in patient autonomy and control, more collective decision-making, and less emphasis on the physician as the sole authority in the clinical or research encounter, it also has struggled with a decreased emphasis on beneficence, increased bureaucratization, and a focus that has centred mainly on rights with lagging recognition of social contexts, stigma, and issues such as access to care and other resources.

Ironically, then, citizens today may be just as wary of bioethics - the very mechanism created to assuage suspicions and feelings of mistrust in medical care.

The second book that germinated as germane when considering "public trust" was the uncomfortably named Min kamp (My Struggle) by Karl Ove Knausgård, a Norwegian writer whose autobiographical tome spans six books and approximately 3,600 pages (Powers 2015). As part of an interdisciplinary faculty reading group (one that began with Marcel Proust [2003], followed by Naguib Mahfouz [2001] and TaNehisi Coates [2015]), a handful of colleagues and I are presently working through Knausgård. Not infrequently, our weekly discussions return, time and again, to the question of "fact versus fiction." Though Knausgård is telling the story —or, well, a story — of his life, each volume is labelled "fiction" on the back cover (Knausgård 2013, 2014, 2015, 2016). And they must be ... to some degree. For how could Knausgård recreate dialogue from a decade back or his childhood or even yesterday? And not even dialogue, but details and thoughts and feelings, that are nothing more than life-aslived until intellectually wrangled, stripped, and coopted through narrative-making and a particularly linear and rationally based narrative-making in the form of the
Western written word? ${ }^{3}$ And, yet, reviewers have called Min kamp "a brutally honest autobiography" that has resulted in "half of his family" not speaking to him (Hoby 2014, I11).

It might well be that any bright line - if it ever existed - between fact and fiction has blurred and faded in today's age (which Knausgård is artistically exploring, even at the peril of his relationships!). Example after example could be brought to bear, including the recent and alarming instance of international nuclear posturing via "fake news" and Twitter (Goldman 2016). Or a newly elected U.S. president who cares little for evidence or apologies (Remnick 2016; Farley 2016). ${ }^{4}$ Like a highly drug-resistant infection, the malady is perhaps easy to spot but difficult to combat and quash, regardless of the evidentiary medicines brought in for the debunking. Policy scholars, cultural critics, and science historians have attempted, and persuasively, to educate the populace on the technologies (some good, some bad) and tactics (often bad) that have brought us here to the confusing corner of "edutainment" (in the Neil Postman [1985] sense of the term) and "missing information" (McKibben 1992). For instance, the 2010 book Merchants of Doubt by Naomi Oreskes and Erik M. Conway and the 2014 documentary of the same name (Kenner et al. 2014) have shown how corporations and others in positions of power have commandeered the inherent ambiguity of science to amplify and even manufacture doubt as an effective go-to play to undermine any inconvenient data (to use an $\mathrm{Al}$ Gore phrase) and thus forestall or prevent possible governmental intervention aimed at promoting public health and safety (see also Markowitz and Rosner 2006). Likewise, the rise of partisan think tanks, "AstroTurf" lobbying, and "talking head experts" and "surrogates" flattens the focus of public conversation and changes it from what could be in-depth, engaged discourse (what with today's

\footnotetext{
${ }^{3}$ This is not to say that Knausgård is not a master in this regard (or that he writes linearly). His writing is deft, evocative, and illuminative of eternal truths within life's banalities. One example, provided infra, doesn't suffice but may provide a taste.

${ }^{4}$ As presidents and other politicians go, Remnick and others have conceded, Donald Trump is not alone here. He has, however, perhaps taken this to a new level while also shining a light (sadly, somehow no longer bright) on the impotent, fleeting attention that pointed-out untruths and hypocrisies today receive. Perhaps there are too many, and we are smothered under their ever-growing burden to take real action. Perhaps, as Neil Postman (1985) warned decades ago, we are simply Amusing Ourselves to Death.
} 
proliferation of channels, air time, and new media) to, albeit often rousing, ad hominem attacks.

As atmospheric physicist James Hansen explains:

The scientific method is you have to continually reassess your conclusions. As soon as there's new data, you ask, "Well, how does that affect my interpretation?" And you're open-minded. What we're up against is people who have a preferred answer, and so then they take the position of a lawyer. They're going to defend their client, and they will only present you with the data that favours their client (interviewed in Kenner et al. 2014). ${ }^{5}$

Some adept at this approach are rather open (and ebullient) about it, underscoring an Aristotelian prohibition against shamelessness. In Merchants of Doubt, Marc Morano, former Republican political aide and current communications director for the Committee for a Constructive Tomorrow (CFACT) and editor of its "climate change denial" ClimateDepot.com website, doesn't shy away from his affection for such "three-card monte" (Kenner et al. 2014). His interview in the film about his time working for former Oklahoma Sen. James Inhofe and the Senate Environment and Public Works Committee bears repeating at length:

In fact, we went after [climate scientists] James Hansen and Michael Oppenheimer and had a lot of fun with it. We mocked and ridiculed James Hansen. I was authorized, I couldn't believe they let me do this, I did a two-part, probably 10,000word, unbelievably scathing critique on James Hansen. I'm not going to question his scientific work, but in terms of his influencing the public. And actually his scientific work isn't really in question, it's more of his public claims and publicity and interviews. I still felt restrained, so I started doing what I call the "the underground newsletters," which went much further than anything else, had a lot more fun, a lot more humour, wit, sarcasm, and sometimes nastiness. That went out and that became the basis for Climate Depot.

\footnotetext{
${ }^{5}$ Not all scientists or at all times, of course, have such pure intentions at heart. Scientists can and have engaged in immoral methods and/or aims or simply become entrenched in positions, clinging to endeared hypotheses, or beholden to grantors or (particularly in the biotech age) their own commercial profits. Rothman's (2009) book, among others, shows clearly what unchecked scientists and clinicians are capable of.
}

This is the new media's new world. [...] [M]ost of the work is happening on the road or in your home office. [...] A lot of it's done in the back of a taxicab, heading to, you know, Fox News or CNN studio, or even on the runway in an airplane. [...] Communication is about sales. Keep it simple. People will fill in the blank with their own, I hate to say biases, but with their own perspective in many cases. [...] I'm not a scientist, although I do play one on TV occasionally. Okay, hell, more than occasionally. You go up against a scientist, most of them are going to be in their own little, sort of policy-wonk world or area of expertise. [...] Very arcane, very hard to understand, hard to explain, and very boring. [...] You, you can't be afraid of the absolute hand-to-hand combat, metaphorically, and you got to name names and you got to go after individuals. You can't just go after a system, and I think that's what I, what I enjoy the most, is going after the individuals, 'cause that's where something lives or dies.

Gridlock is the greatest friend a global warming sceptic has, 'cause that's all you really want. You can't, there's no, you know, there's no legislation we're championing. All we're, we're the negative force, we're just trying to stop stuff (interviewed in Kenner et al. 2014, emphasis original).

Where does this leave public trust?

Unlike Henry Beecher, for example, who refused to "name names" in his 1966 article "Ethics and Clinical Research" in order to address a moral problem through consciousness raising with the intent of changing the system (Harkness, Lederer, and Wikler 2001), ${ }^{6}$ much of today's "news" coverage seems to resort to this (whether warranted or not), with the aim of misdirecting the conversation, and thus investigation, away from issues at hand that might have practicable solutions and focusing instead on superficial appeals to emotion and ideology (see, e.g., Goodman et al. 2004).

As science historian Naomi Oreskes explains: "This is a debate, but this is not a scientific debate. And if it's

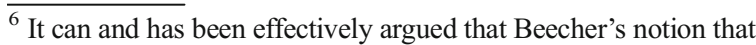
physicians could "police themselves," with education and urgings to become more virtuous clinicians and scientists, isn't sufficient - thus the need for a more formal, third-party-laden bioethics. That said, as Harkness, Lederer, and Wikler state, Beecher's approach against naming names "proved to have greater immediate influence on the conduct of research" $(2001,366)$.
} 
not a scientific debate, then the question becomes: Well, what sort of a debate is it?" (interviewed in Kenner et al. 2014). A sadly amusing one, certainly, but one where evidence is malleable and only the loudest (and/or most well-funded) voices - shilling a short-sighted, PRconstructed version of what is or ought to be-matter. And, thus, it seems we are all hamsters running the wheel, fighting a "freedom versus regulation" straw man while accepting the negative externalities of many free-market policies and ignoring the fact that true freedom - and even (at least long-term) the more economically lucrative freedom, for those in business and industry - might be effective, rather than formal, freedom.

The symposium on "Public Trust in Expert Knowledge" in this issue of the $J B I$ addresses many of these questions and concerns, with an overall aim of how we can change our public conversations and increase trust in a way that benefits all. It includes, for example, articles on vaccine hesitancy and gestational diabetes testing, papers whose "data show how perceptions of the profit motive generate distrust in the expert systems pertaining to [issues such as] vaccination" (Attwell et al. 2016, under "Abstract") and that parents" "discovery that biomedicine does not speak in one voice ruptures their trust in medical authority" (Edwell and Jack 2016, under "Abstract"). Buchman, Ho, and Goldberg (2016) also discuss the epistemic downgrading of pain sufferers' narratives in the therapeutic relationship; Wong the integral role trust plays in "the exchange between donors, recipients, and gamete agencies in donor conception" and how trust "heavily informs concepts of relatedness, race, ethnicity, kinship, class, and visibility" (2017, under "Abstract"); and Bowman how public engagement is "unhelpfully [characterized and] constrained by a systemic disposition which continues to privilege the professional or expert voice at the expense of meaningful exchange and dialogue" (2017, under "Abstract"). (Of course, thanks to approaches like those described by Morano, it's not always easy to discern exactly who is an "expert" anymore, anyway.) Like the other authors in this issue, Bowman also offers ways to alter today's course and "creat $[\mathrm{e}]$ space for novel interactions between the 'expert' and the 'public," so that "authentic engagement is achieved that enables not only the participants to flourish but also contributes to trust itself" (Bowman 2017, under "Abstract").

Of course, as artists and scholars of narrative have long recognized, all stories are concocted, only loosely based on life-as-lived and always crafted with specific audiences and goals in mind (Mattingly 1998). As literature, Knausgård doesn’t seem that concerned with defining what or "how real" his story is. It is through this not quite fact-driven fiction that he illuminates the nature not of the human beings in his life (though his relatives might still have cause for action) but human Being. And we reflect, too, and learn of ourselves while sharing in Knausgård's reimagined autobiography.

But intentionally confusing fact and fiction and data versus opinion in science and policy undermines the human endeavour, both short- and long-term, and makes the proliferation of information and voices in the digital age (which can be rather beneficial) and the task of trusting that much more complex.

From an academic publishing perspective, journals and authors are at a crossroads. Academic peer-review, though an imperfect process to be sure, has sought to be the foundation of trust in expert knowledge, but such "slow-food" research and analysis is often a remote (and, as Morano a bit-too-gleefully states, unengaging) source for the general public and it has struggled to compete with the "fast-food" lane of other media and information. Bridging such gaps, broaching better public discourse, and breaking through the "clutter crisis" of today's mediated age (Goodman et al. 2004) are and will continue to be essential tasks for scholars, academic publications, and policymakers committed to public welfare and global stewardship and looking beyond quarterly returns.

Failing to counteract the misdirection, revive public trust, and promote ethical solutions to current and looming problems is to disappear, metaphorically and perhaps actually, into nothingness. Misdirection, according to magician Jamy Ian Swiss,

is the use of the little lie to sell the big lie. [...] So, really misdirection is about focus. It's not so much about directing away or misdirecting, it's about direction. It's about bringing your attention to something that engages you. And then, you don't see anything else in the frame (interviewed in Kenner et al. 2014, emphasis original).

In the second volume of his Min kamp, Knausgård, walking with his wife along a lake and into the forest near Gnesta, Sweden, ruminates on the risk of this as well: 
Around us all was perfectly still, apart from the occasional whoosh as the wind gusted through the forest. For the first time in ages I had some peace in my soul. Even if snow lay thick on the ground everywhere and white is a bright color, the brightness didn't dominate the terrain, because out of the snow, which so sensitively reflects the light from the sky and always gleams, however dark it is, rose tree trunks, and they were gnarled and black, and branches hung above them, also black, intertwining in an endless variety of ways. The mountainsides were black, the stumps and debris of blown-down trees were black, the rock faces were black, the forest floor was black beneath the canopy of enormous spruces.

The soft whiteness and the gaping blackness both were perfectly still, and it was impossible not to be reminded of how much of what surrounded us was dead, how little of it all was actually alive and how much space the living occupied inside us. This is why I would have loved to be able to paint, would have loved to have the talent, for it was only through painting this could be expressed. [...] When I was outdoors, walking, like now, what I saw gave me nothing. Snow was snow, trees were trees. It was only when I saw a picture of snow or of trees that they were endowed with meaning. Monet had an exceptional eye for light on snow, which Thaulow, perhaps technically the most gifted Norwegian painter ever, also had. It was a feast for the eyes, the closeness of the moment was so great that the value of what gave rise to it increased exponentially, an old tumbledown cabin by a river or a pier at a holiday resort suddenly became priceless, the paintings were charged with the feeling that they were here at the same time as us, in this intense here and now, and that we would soon be gone from them, but with regard to the snow, it was as if the other side of this cultivation of the moment became visible, the animation of this and its light so obviously ignored something, namely the lifelessness, the emptiness, the noncharged and the neutral, which were the first features to strike you when you entered a forest in winter, and in the picture, which was connected with perpetuity and death, the moment was unable to hold its ground. Caspar David Friedrich knew this, but this wasn't what he painted, only his idea of it. This was the problem with all representation, of course, for no eye is uncontaminated, no gaze is blank, nothing is seen the way it is. And in this encounter the question of art's meaning as a whole was forced to the surface. Yes, okay, so I saw the forest here, so I walked through it and thought about it. But all meaning I extracted from it came from me, I charged it with something of mine. If it were to have any meaning beyond that, it couldn't come from the eyes of the beholder, but through action, through something happening, that is. Trees would have to be felled, houses built, fires lit, animals hunted, not for the sake of pleasure but because my life depended on it. Then the forest would be meaningful, indeed, so meaningful that I would no longer wish to see it (Knausgård 2014, 431-434).

\section{References}

Attwell, K., J. Leask, S.B. Meyer, P. Rokkas, and P. Ward. 2016. Vaccine rejecting parents' engagement with expert systems that inform vaccination programs. Journal of Bioethical Inquiry 14(1). doi:10.1007/s11673-016-9756-7.

Beecher, H.K. 1966. Ethics and clinical research. The New England Journal of Medicine 274(24): 1354-1360.

Bowman, D. 2017. The moral of the tale: Stories, trust, and public engagement with clinical ethics via radio and theatre. Journal of Bioethical Inquiry 14(1). doi:10.1007/s11673-016-9766-5.

Buchman, D.Z., A. Ho, and D.S. Goldberg. 2016. Investigating trust, expertise, and epistemic injustice in chronic pain. Journal of Bioethical Inquiry 14(1). doi:10.1007/s11673016-9761-x.

Camporesi, S., D.Z. Buchman, A. Ho, D.S. Goldberg, and L.E. Rich. 2016. Public trust in expert knowledge: Narrative, ethics and engagement. Panel session at the annual meeting for the American Society for Bioethics + Humanities, October 6-9, in Washington, D.C.

Camporesi, S., M. Davis, and M. Vaccarella. 2017. Investigating public trust in expert knowledge: Narrative, ethics, and engagement. Journal of Bioethical Inquiry 14(1). doi:10.1007/ s11673-016-9767-4.

Coates, T.-N. 2015. Between the world and me. New York: Spiegel \& Grau.

Edwell, J., and J. Jack. 2016. Gestational diabetes testing, narrative, and medical distrust. Journal of Bioethical Inquiry 14(1). doi:10.1007/s11673-016-9762-9.

Farley, R. 2016. Trump on the stump: We are checking the accuracy of claims made by the presidential candidates in their daily stump speeches. First up: Trump. FactCheck.org, September 28. http://www.factcheck.org/2016/09/trump-onthe-stump/ . Accessed January 5, 2017.

Goldman, R. 2016. Reading fake news, Pakistani minister directs nuclear threat at Israel. The New York Times, December 24. http://www.nytimes.com/2016/12/24/world/asia/pakistan- 
israel-khawaja-asif-fake-news-nuclear.html? $\mathrm{r}=0$. Accessed January 5, 2017.

Goodman, B., and R. Dretzin (directors) and B. Goodman and D. Rushkoff (writers). 2004. The persuaders. In Frontline, produced by R. Dretzin, B. Goodman, and M. Soenens, November 9, season 22, episode 15. Boston: WGBH Educational Foundation and WGBH Boston.

Harkness, J., S.E. Lederer, and D. Wikler. 2001. Laying ethical foundations for clinical research. Bulletin of the World Health Organization 79(4): 365-366.

Heller, J. 1972. Syphilis victims in U.S. study went untreated for 40 years. The New York Times, July 26, 1, 8.

Hoby, H. 2014. Karl Ove Knausgaard: Norway's Proust and a life laid painfully bare. The Guardian, March 1. https://www. theguardian.com/theobserver $/ 2014 / \mathrm{mar} / 01 / \mathrm{karl}$-oveknausgaard-norway-proust-profile. Accessed October 6, 2016.

Kenner, R. (director), and R. Kenner, K. Roberts, N. Oreskes, and E.M. Conway (writers). 2014. Merchants of doubt. Los Angeles: Participant Media.

Knausgård, K.O. 2013. My struggle: Book one: A death in the family. Translated by D. Bartlett. New York: Farrar, Straus and Giroux. Originally published as Min kamp: Første bok (Oslo: Forgalet Oktober, 2009).

Knausgård, K.O. 2014. My struggle: Book two: A man in love. Translated by D. Bartlett. New York: Farrar, Straus and Giroux. Originally published as Min kamp: Andre bok (Oslo: Forgalet Oktober, 2009).

Knausgård, K.O. 2015. My struggle: Book three: Boyhood island. Translated by D. Bartlett. New York: Farrar, Straus and Giroux. Originally published as Min kamp: Tredje bok (Oslo: Forgalet Oktober, 2009).

Knausgård, K.O. 2016. My struggle: Book four: Dancing in the dark. Translated by D. Bartlett. New York: Farrar, Straus and Giroux. Originally published as Min kamp: Fjerde bok (Oslo: Forgalet Oktober, 2010).

Mahfouz, N. 2001. The Cairo trilogy: Palace Walk, Palace of Desire, Sugar Street. Translated by W.M. Hutchins and O.E. Kenny; W.M. Hutchins, L.M. Kenny, and O.E. Kenny; and W.M. Hutchins and A.B. Samaan, respectively. New York: Everyman's Library/Alfred A. Knopf. Originally published as Bayn al-Qasrayn (1956), Qasr al-Shawq (1957), and AlSukkariyya (1957).

Markowitz, G., and D. Rosner. 2006. Building a toxic environment: Historical controversies over the past and future of public health. In History and health policy in the United States: Putting the past back in, edited by R.A. Stevens, C.E. Rosenberg, and L.R. Burns, 130-150. Piscataway, NJ: Rutgers University Press.

Mattingly, C. 1998. Healing dramas and clinical plots: The narrative structure of experience. Cambridge: Cambridge University Press.

McKibben, B. 1992. The age of missing information. New York: Random House.

Oreskes, N., and E.M. Conway. 2010. Merchants of doubt: How a handful of scientists obscured the truth on issues from tobacco smoke to global warming. New York: Bloomsbury Press.

Postman, N. 1985. Amusing ourselves to death: Public discourse in the age of show business. New York: Viking.

Powers, J. 2015. 3,600-page autobiographical novel is an honest and masterful "selfie." National Public Radio, April 29. http://www.npr.org/2015/04/29/403046849/3-600-page-autobiographical-novel-is-an-honest-and-masterful-selfie. Accessed February 4, 2017.

Proust, M. 2003. In search of lost time, vols. 1-6. Translated by C.K.S. Moncrieff and T. Kilmartin, revised by D.J. Enright. New York: Modern Library. Originally published as $\dot{A} l a$ recherche du temps perdu (Paris: Grasset and Gallimard, 1913-1927).

Remnick, D. 2016. Introducing a new series: Trump and the truth. The New Yorker, September 2. http://www.newyorker. $\mathrm{com} /$ news/news-desk/introducing-a-new-series-trump-andthe-truth. Accessed January 5, 2017. The full series can be found at http://www.newyorker.com/topics/trump-truth-factchecking-investigation.

Rothman, D.J. 2009. Strangers at the bedside: A history of how law and bioethics transformed medical decision making. New Brunswick and London: Aldine Transaction.

Wong, K-A. 2017. Donor conception and "passing," or; Why Australian parents of donor-conceived children want donors who look like them. Journal of Bioethical Inquiry 14(1). doi: 10.1007/s11673-016-9755-8. 